\title{
Differences in In Vitro Properties of Pancreatin Preparations for Pancreatic Exocrine Insufficiency as Marketed in Russia and CIS
}

\author{
Igor V. Maev ${ }^{1} \cdot$ Yury A. Kucheryavyy ${ }^{1} \cdot$ Natalya B. Gubergrits $^{2} \cdot$ Ingo Bonnacker $^{3} \cdot$ Ekaterina A. Shelest $^{4}$. \\ Gwendolyn P. Janssen-van Solingen ${ }^{5}$ (D) J. Enrique Domínguez-Muñoz ${ }^{6}$
}

Accepted: 9 October 2020 / Published online: 19 November 2020

(c) The Author(s) 2020

\begin{abstract}
Background Pancreatic enzyme-replacement therapy (PERT), provided as pancreatin to patients with pancreatic exocrine insufficiency (PEI), is considered an essential substitute for the pivotal physiological function the pancreas fulfills in digestion. PEI involves a reduction in the synthesis and secretion of pancreatic enzymes (lipase, protease, amylase), which leads to an inadequate enzymatic response to a meal and consequently to maldigestion and malabsorption of nutrients. The efficacy of PERT is strongly dependent on enzyme activity, dissolution, and pancreatin particle size.

Objective The physiological properties of eight pancreatin preparations (nine batches; five different brands) available in Russia and CIS (Commonwealth of Independent States: Armenia, Azerbaijan, Belarus, Kazakhstan, Kyrgyzstan, Moldova, Russia, Tajikistan, Uzbekistan) were investigated.

Methods The lipase activity, dissolution, and particle size distribution of samples from multiple batches of pancreatin of different strengths were measured.

Results Regarding lipase activities, all pancreatin preparations except Micrazim ${ }^{\circledR}$ matched the labeled content. Considerable differences were observed in particle size and dissolution.

Conclusion Pancreatin preparations available in Russia and CIS demonstrate product-to-product and batch-to-batch variability regarding the measured properties of lipase activity, dissolution, and particle size. This may impact the efficacy of PERT and therefore clinical outcomes.
\end{abstract}

\section{Introduction}

Pancreatic exocrine insufficiency (PEI) is defined as an insufficient secretion of pancreatic enzymes (acinar function) and/or sodium bicarbonate (ductal function), with the main causes being loss of pancreatic parenchyma, obstruction of the main pancreatic duct, decreased stimulation of the exocrine pancreas and inactivation of pancreatic enzymes

Gwendolyn P. Janssen-van Solingen gwendolyn.janssen@abbott.com

1 A.I. Evdokimov Moscow State University of Medicine and Dentistry, Ministry of Health of Russia, Moscow, Russia

2 Donetsk National Medical University, Ministry of Health of Ukraine, Lyman, Ukraine

3 Abbott Laboratories GmbH, Hannover, Germany

4 Abbott Laboratories, Moscow, Russia

5 Abbott Product Operations AG, Allschwil, Switzerland

6 Department of Gastroenterology and Hepatology, University Hospital of Santiago de Compostela, Santiago de Compostela, Spain [1]. The pancreas has a large reserve capacity; patients with pancreatic secretion $<10 \%$ are classified as having severe or decompensated insufficiency, with the key clinical manifestation of PEI tending to be steatorrhea. Nonetheless, patients classified as having mild to moderate exocrine insufficiency may also experience malnutrition, malabsorption of lipidsoluble vitamins, and depleted micronutrients which, in turn, is associated with high morbidity and mortality [1-3].

In the past 5 years, several guidelines have been published regarding the diagnosis and management of PEI, especially considering the underlying etiology of chronic pancreatitis $(\mathrm{CP})$, but also related to PEI irrespective of underlying disease. In 2015, the Australasian guidelines for 


\section{Key Points}

Pancreatic Enzyme Replacement Therapy (PERT) is considered the treatment of choice for the management of Pancreatic Exocrine Insufficiency (PEI).

This in-vitro study assessed the properties of pancreatin preparations for PEI as available in Russia/CIS regarding particle size, lipase activity and dissolution.

The properties assessed are considered to impact the efficacy of PERT as the objective of PERT is to mimic the normal physiological process of digestion. Factors contributing to the efficacy are: mixture with a meal, gastric emptying with a meal, mixing with duodenal chyme/bile acids, rapid release of enzymes in the duodenum as well as enzyme activity.

The investigated pancreatin preparations demonstrate variability regarding the investigated parameters, particularly for particle size, but differences were also noted regarding actual vs. labeled lipase activity and dissolution rates. The observed differences may impact the efficacy of PERT, although caution should be exerted when extrapolating in vitro study results to clinical outcomes.

the management of PEI were published [4, 5]. In Europe, the United European gastroenterology evidence-based guidelines for the diagnosis and therapy of CP (HaPanEU) were published in 2017 [1]. This overarching European guideline followed a whole range of local guidelines published between 2010 and 2015 (Italian in 2010, Spanish in 2013, and German, Hungarian, and Romanian in 2015) [6-11]. Whereas these guidelines consistently recommended $\mathrm{pH}$ sensitive, enteric-coated pancreatin preparations, most but not all specifically alluded to the importance of particle size.

The most recently published European guideline [1] stated that the efficacy of pancreatic enzyme-replacement therapy (PERT) depends on several factors: mixture with a meal, gastric emptying with meal, mixing with the duodenal chyme and bile acids and rapid release of enzymes in duodenum.

For PERT, the particle size, acid resistance, and dissolution profile are important features of pancreatin preparations intended to mimic the normal physiological process of digestion.

In a Cochrane analysis from 2014, Somaraju et al. [12] reported a statistically significant result favoring entericcoated microspheres over enteric-coated tablets for secondary outcomes of stool frequency, abdominal pain, and fecal fat excretion. The HaPanEU guidelines from 2017 confirmed this finding, stating that "enteric-coated microspheres or mini-microspheres of $<2 \mathrm{~mm}$ in size are the preparations of choice for PEI. Micro- or minitablets of $2.2-2.5 \mathrm{~mm}$ in size may be also effective, although scientific evidence in the context of $\mathrm{CP}$ is more limited and comparative clinical trials of different enzyme preparations are lacking" [1].

In two previous publications, Löhr et al. [13, 14] specified the additional criteria an ideal pancreatic enzyme supplement would need to fulfill, specifically related to the following properties:

(1) Rapid enzyme release in the small intestine at approximately $\mathrm{pH} 6$ with 2 -h efficacy.

(2) Particle size $<1.7 \mathrm{~mm}$ to pass the pylorus.

(3) Large specific surface area.

(4) Conformity of ingredients with label declaration.

(5) High batch-to-batch conformity.

Conformity of ingredients with label declaration is important for adequate dosing, especially regarding lipase activity, and dosing of PERT in cystic fibrosis is either by grams of fat ingested or bodyweight. Dosing by grams of fat is more likely to mimic the normal pancreatic response to a meal. Doses of enzymes exceeding 2500 lipase units $/ \mathrm{kg} /$ meal or 4000 lipase units/g of fat warrant further investigation in cystic fibrosis [15].

The results of a comparison of the properties and formulation characteristics of various pancreatin preparations in Western Europe have been published before [14]. The aforementioned study analyzed different strengths of Kreon ${ }^{\circledR}$, Panzytrat ${ }^{\circledR}$, Pangrol ${ }^{\circledR}$, Cotazym ${ }^{\circledR}$, Ozym $\AA$, and Pankreatin ${ }^{\circledR}$ (Mikro-ratiopharm). Regarding enzyme preparations available in Russia and CIS there is some overlap regarding preparations assessed in 2009, but there are also significant differences.

The aim of this study was to compare the properties and formulation characteristics of pancreatin capsules of different strengths and brands $\left(\right.$ Micrazim ${ }^{\circledR}$, Ermytal ${ }^{\circledR}$, Pangrol ${ }^{\circledR}$, Panzytrat ${ }^{\circledR}$, Kreon $\left.{ }^{\circledR}\right)$.

\section{Materials and Methods}

\subsection{Materials}

In the current study, we analyzed the lipase activities, dissolution, and particle sizes of samples from nine batches of pancreatin capsules of different strengths (brand names Micrazim ${ }^{\circledR}$, Ermytal ${ }^{\circledR}$, Pangrol ${ }^{\circledR}$, Panzytrat ${ }^{\circledR}$, Kreon $\left.{ }^{\circledR}\right)$. All measurements were performed in duplicate per batch, except for Kreon, which was performed in triplicate per batch. All tested products had a gastro-resistant coating, since lipase is irreversibly inactivated at a $\mathrm{pH}$ of $\leq 4$.

The pancreatin supplements assessed consisted of capsules filled with microtablets, minitablets, pellets, or minimicrospheres The following commercial batches of pancreatin 
Table 1 Overview of products investigated

\begin{tabular}{|c|c|c|c|c|c|}
\hline Brand name (manufacturer) & $\mathrm{LC}(\mathrm{L}, \mathrm{A}, \mathrm{P})$ & Batch & Manufacturing date & Expiry date & Capsule size and content \\
\hline $\begin{array}{l}\text { Ermytal }{ }^{\circledR} 25,000 \\
\text { (Nordmark, Germany) }\end{array}$ & $\begin{array}{l}25000 \\
22500 \\
1250\end{array}$ & 330401 & May 2017 & Apr 2020 & Capsules size 0el, with microtablets \\
\hline $\begin{array}{l}\text { Ermytal@ } 36,000 \\
\text { (Nordmark, Germany) }\end{array}$ & $\begin{array}{l}36000 \\
18000 \\
1200\end{array}$ & 110421 & Feb 2015 & Jan 2018 & Capsules, size 00, with microtablets \\
\hline $\begin{array}{l}\text { Kreon }{ }^{\circledR} 25,000 \\
\text { (Abbott, Germany) }\end{array}$ & $\begin{array}{l}25000 \\
18000 \\
1000\end{array}$ & 0293 & Oct 2017 & Sep 2020 & Capsules, size 0 , with minimicrospheres \\
\hline $\begin{array}{l}\text { Kreon }{ }^{\circledR} 25,000 \\
\text { (Abbott, Germany) }\end{array}$ & $\begin{array}{l}25000 \\
18000 \\
1000\end{array}$ & 0296 & Oct 2017 & Sep 2020 & Capsules, size 0 , with minimicrospheres \\
\hline $\begin{array}{l}\text { Kreon }{ }^{\circledR} 40,000 \\
\text { (Abbott, Germany) }\end{array}$ & $\begin{array}{l}40000 \\
25000 \\
1600\end{array}$ & 0014 & Aug 2017 & Jul 2020 & Capsules, size 00 , with minimicrospheres \\
\hline $\begin{array}{l}\text { Micrazim }{ }^{\circledR} \\
25,000 \\
\text { (AVVA RUS, Russia) }\end{array}$ & $\begin{array}{l}25000 \\
19000 \\
1300\end{array}$ & 330417 & NA & Apr 2019 & Capsules, size 0 , with pellets \\
\hline $\begin{array}{l}\text { Micrazim }{ }^{\circledR} \\
40,000 \\
\text { (AVVA RUS, Russia) }\end{array}$ & $\begin{array}{l}40000 \\
30240 \\
2080\end{array}$ & 10716 & NA & Jul 2019 & Capsules, size 00, with pellets \\
\hline $\begin{array}{l}\text { Pangrol } ® 25,000 \\
\text { (Adare Pharmaceuticals, Italy) }\end{array}$ & $\begin{array}{l}25000 \\
22500 \\
1250\end{array}$ & 71200 & Mar 2017 & Mar 2019 & Capsules, size 0el, with minitablets \\
\hline $\begin{array}{c}\text { Panzytrat }{ }^{\circledR} 25,000 \text { (Allergan } \\
\text { Pharmaceuticals, Ireland) }\end{array}$ & $\begin{array}{l}25000 \\
22500 \\
1250\end{array}$ & 410101 & NA & Jun 2020 & Capsules, size 0 , with microtablets \\
\hline
\end{tabular}

$A$ amylase, $L$ lipase, $L C$ labeled content (FIP U), $P$ proteases

capsules were acquired from public pharmacies and investigated within their shelf-life: Micrazim ${ }^{\circledR} 25,000$, Micrazim $®$ 40,000, Pangrol ${ }^{\circledR} 25,000$, Ermytal ${ }^{\circledR} 25,000$ and 36,000, and Panzytrat ${ }^{\circ} 25,000$. The study also included data from Kreon ${ }^{\circledR}$ 25,000 (two batches) and 40,000 (one batch) and the particle size distributions of all these strengths (Table 1). An overview of the different products is given in Table 1.

\subsection{Determination of Particle Size}

Particle size distribution (PSD) was determined using a Qicpic dynamic imaging system (Sympatec GmbH, Germany), applying the same measuring conditions for all samples. The system can differentiate between length (Ferret max) and width (Ferret min) for each particle (method details may be requested from the corresponding author). Each batch was analyzed in duplicate (different brands) or in triplicate (Kreon $®$ samples). The number of repetitions depended on the available amount of test material.

The form/shape of the tablets and pellets investigated in this study are best described as a cylinder. The length of these cylinders was considered the critical dimension that determined the probability of passing the pylorus together with the chyme. However, the particle size of tablets is well-defined by the manufacturing process and does not have a wide distribution. In contrast, pellets have a wider distribution. The Ferret $\max ^{1} \mathrm{X}_{50}$ was used as the representative parameter for the overall PSD. The $\mathrm{X}_{50}$ value is the particle diameter, for which the cumulative distribution Q3 (volume based) assumes a value of $50 \%$. Particle sizes were represented with the aid of the percentile range $\mathrm{X}_{50}$, where $\mathrm{X}_{50}$ represents the particle size at which $50 \%$ of the material is smaller than this.

\subsection{Enzyme Activity Determination}

The strengths of the pancreatin products are defined by the labeled lipase activity. Lipase activities were determined according to the European Pharmacopoeia (Ph. Eur.) [16]. The lipase activity of the product was determined by comparing the hydrolysis of olive oil emulsion (lipolytic activity) achieved by the product and that determined for the welldefined reference standard.

\footnotetext{
${ }^{1}$ Source: https://www.sympatec.com/en/particle-measurement/gloss ary/particle-shape/.
} 
Table 2 Particle size distributions of the investigated products

\begin{tabular}{|c|c|c|}
\hline Product & Batch & $\begin{array}{l}X_{50} \\
\text { Qicpic } \\
\text { Ferret } \\
(\max ) \\
(\mu \mathrm{m})\end{array}$ \\
\hline Ermytal ${ }^{\circledR} 25,000$ (mean, $\left.n=2\right)$ & 330401 & 2725 \\
\hline Ermytal ${ }^{\circledR} 36,000$ (mean, $\left.n=2\right)$ & 110421 & 2737 \\
\hline Kreon ${ }^{\circledR} 25,000$ (mean, $n=3$ ) & 0293 & 1526 \\
\hline Kreon ${ }^{\circledR} 25,000$ (mean, $n=3$ ) & 0296 & 1654 \\
\hline Kreon ${ }^{\circledR} 40,000$ (mean, $n=3$ ) & 0014 & 1667 \\
\hline Micrazim $® 25,000$ (mean, $n=2$ ) & 33041 & 2181 \\
\hline Micrazim ${ }^{\circledR} 40,000$ (mean, $n=2$ ) & 10716 & 2079 \\
\hline Pangrol ${ }^{\circledR} 25,000($ mean, $n=2)$ & 71200 & 2746 \\
\hline Panzytrat ${ }^{\circledR} 25,000$ (mean, $n=2$ ) & 410101 & 2736 \\
\hline
\end{tabular}

\subsection{Dissolution}

Pancreatin formulations are coated with a $\mathrm{pH}$-sensitive coating intended to dissolve above the safe $\mathrm{pH}$ threshold of 5-5.5. Dissolution testing was performed on qualified equipment (dissolution tester Sotax ATR smart) and lipase activity was determined in the dissolution media according to the Ph. Eur. (hydrolysis of olive oil vs. the reference standard). The dissolution conditions are a modification of the US Pharmacopoeia (USP) method described for pancrelipase delayed-release capsules [17]. The pellets were placed in synthetic gastric juice ( $\mathrm{pH} 1.15)$ for $2 \mathrm{~h}$, then transferred to a phosphate buffer with $\mathrm{pH}$ 6. Samples were taken after 20 and $30 \mathrm{~min}$ in phosphate buffer and the lipase activity determined.

Deviation from the standard dissolution analyses occurred for Micrazim ${ }^{\circledR} 25,000$, although only limited material was available so this was performed with two vessels instead of six.

\section{Results}

\subsection{Particle Size Distribution}

The particle diameter of the pancreatin preparations differed considerably. Table 2 and Fig. 1 summarize the results of the particle size determination (PSD). The particle size data demonstrate that $\mathrm{Kreon}{ }^{\circledR}$ has the smallest particle size for Ferret $\max \mathrm{X}_{50}$ of all the products. All tablet formulations (Ermytal ${ }^{\circledR}$, Pangrol ${ }^{\circledR}$, Panzytrat ${ }^{\circledR}$ ) are significantly larger than $2000 \mu \mathrm{m}$. The pellet formulations for Micrazim ${ }^{\circledR}$ have a particle size slightly larger than $2000 \mu \mathrm{m}$; the minimicrospheres for Kreon ${ }^{\circledR}$ are below $1700 \mu$ m (Fig. 1).

\subsection{Lipase Activities}

The lipase activities in the analyzed batches per pancreatic enzyme supplement are summarized in Table 3. We noted small deviations from the declared content, with values of $96-122 \%$, with Micrazim ${ }^{\circledR} 40,000$ being a significant outlier at $79 \%$ (Fig. 2).

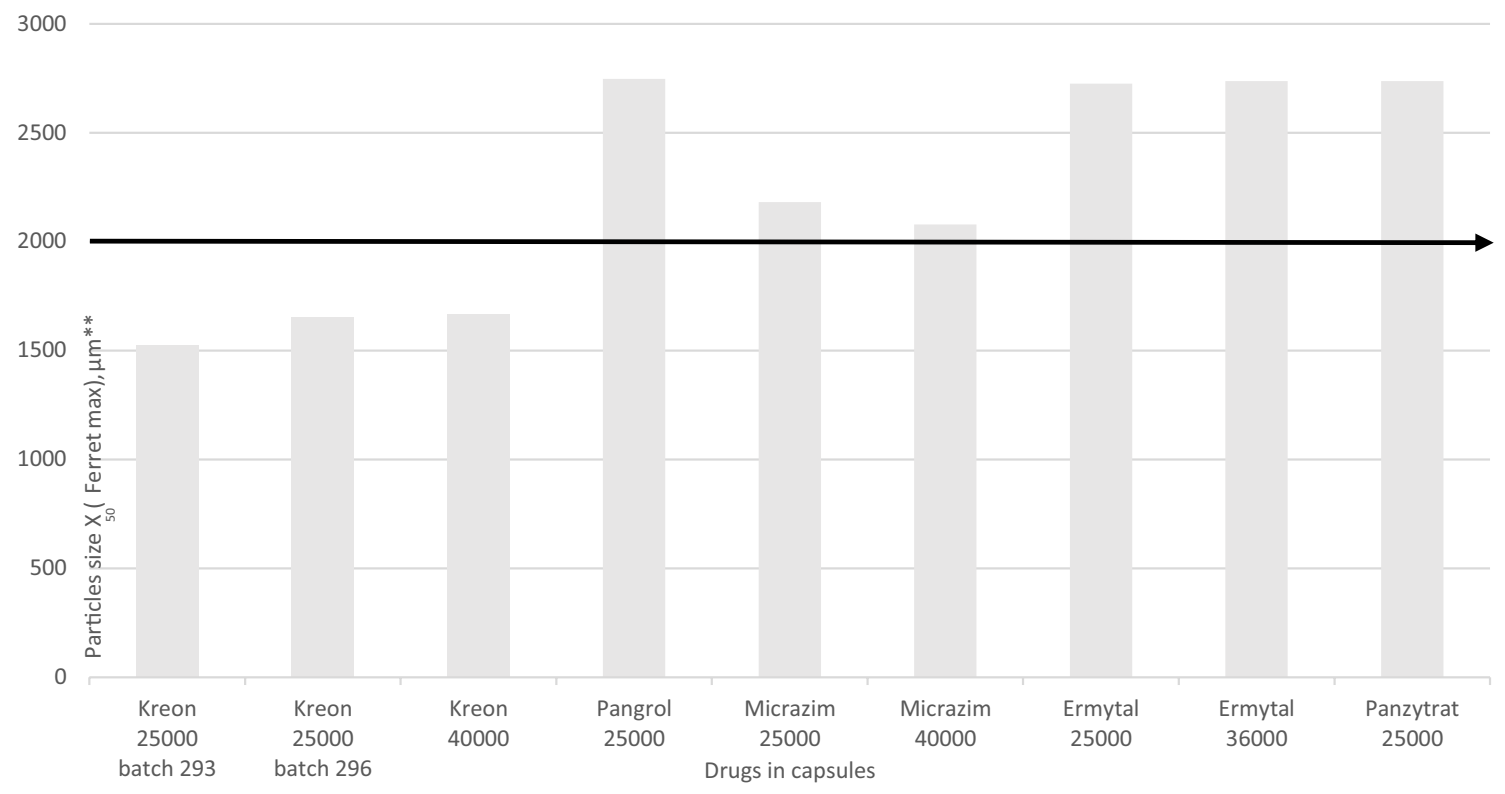

Fig. 1 Particle size $(\mu \mathrm{m})$ of pancreatin preparations in Russia/CIS capsules expressed as Ferret $\max \mathrm{X}_{50}$. The continuous line at the $2000 \mu \mathrm{m}$ level represents the largest particle size recommended in clinical guidelines for the treatment of pancreatic exocrine insufficiency. **In the case of two samples, mean value of two samples 


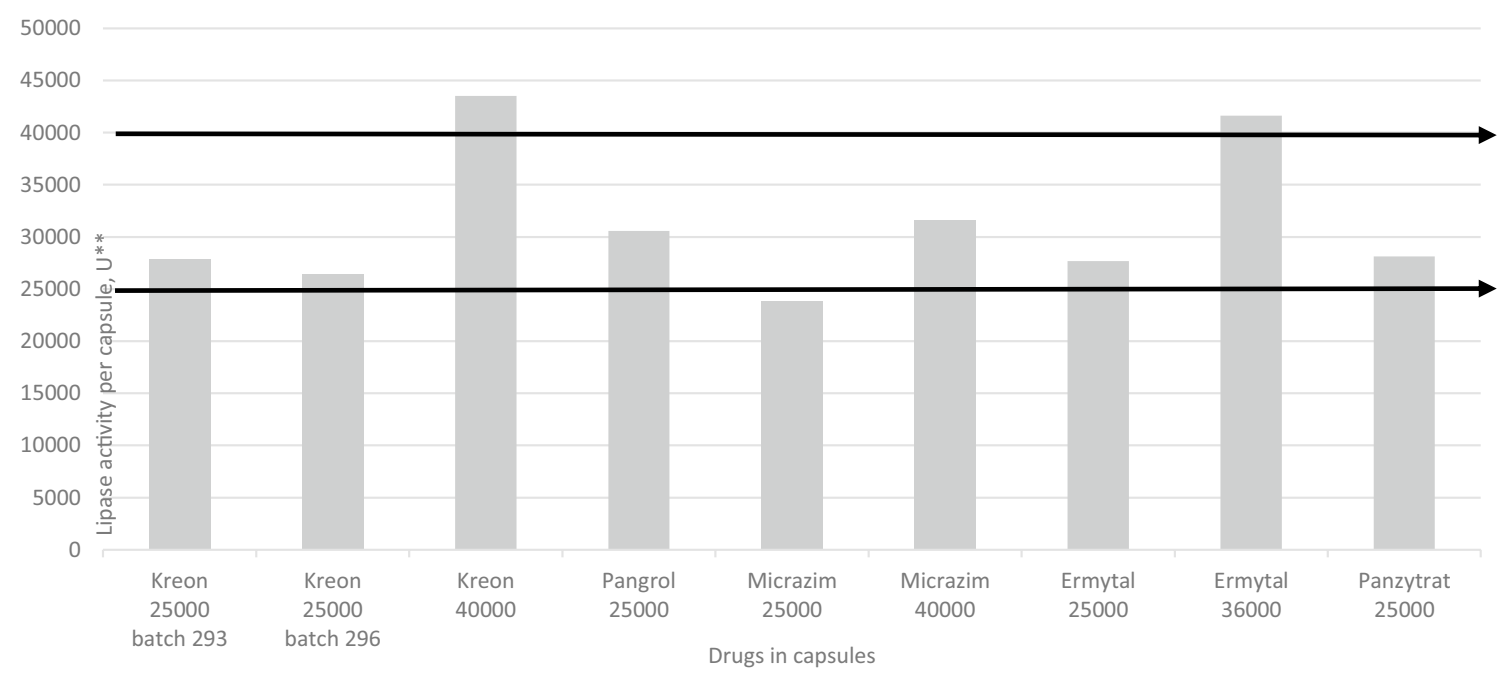

Fig. 2 Lipase activity of the different products. **In the case of two samples, mean value of two samples

Table 3 Determined enzyme activities per capsule and expressed as percent of labeled lipase activity (LC)

\begin{tabular}{lllll}
\hline Product & Batch & Enzyme & $\begin{array}{l}\text { Activity per } \\
\text { capsule (FIP U/ } \\
\text { cps) }\end{array}$ & LC (\%) \\
\hline Ermytal ${ }^{\circledR 25,000}$ & 330401 & Lipase & 27,678 & 111 \\
Ermytal ${ }^{\circledR 3,000}$ & 110421 & Lipase & 41,641 & 116 \\
Kreon ${ }^{25,000}$ & 0293 & Lipase & 27,840 & 111 \\
Kreon ${ }^{\circledR 25,000}$ & 0296 & Lipase & 26,405 & 106 \\
Kreon ${ }^{4} 40,000$ & 0014 & Lipase & 43,515 & 109 \\
Micrazim ${ }^{2} 25,000$ & 33041 & Lipase & 23,871 & 96 \\
Micrazim ${ }^{\circledR 40,000}$ & 10716 & Lipase & 31,631 & 79 \\
Pangrol® 25,000 & 71200 & Lipase & 30,558 & 122 \\
Panzytrat ${ }^{\circledR 25,000}$ & 410101 & Lipase & 28,133 & 113 \\
\hline
\end{tabular}

$L C$ labeled content

All lipase activities were at or above the label claim, except for Micrazim ${ }^{\circledR}$, where lipase activities were consistently below the label claim. The Ph. Eur. does not list a monograph on pancreas powder-finished products, but the USP contains a monograph on pancrelipase delayed-release capsules [17], which provides a minimum lipase activity of $90 \%$. All tested products corresponded to this acceptance criteria, except for Micrazim ${ }^{\circledR} 40,000$, for which only $79 \%$ of labeled activity was determined.

\subsection{Dissolution}

Table 4 presents the mean (of six vessels) as well as the coefficient of variation (CV) at each respective timepoint. Figure 3 demonstrates the dissolution of the different products after $20 \mathrm{~min}$ as percent of labeled lipase activity.
All products but Micrazim ${ }^{\circledR} 40,000$ demonstrated an average dissolution rate of more than $80 \%$ for at least one time point. This is consistent with the determined lipase activity for this batch. Therefore, it can be concluded that the gastric-resistance and dissolution characteristics of the different products are comparable.

\section{Discussion}

In clinical practice, the dose of pancreatic enzymes administered is based on lipase activity, where the recommended initial dose reflects approximately $10 \%$ of the physiologically secreted dose of lipase into the duodenum after consumption of a normal meal. For digestion of a normal meal, this translates into a minimum lipase activity of 30,000 IU. Since $1 \mathrm{IU}$ of lipase equals $3 \mathrm{PhU}$, the minimum amount of lipase required to digest a normal meal is $90,000 \mathrm{PhU}$, which can be achieved by a combination of endogenous enzyme secretion and exogenous enzyme administration. The aforementioned HaPanEU guidelines [1] therefore advocate a minimum lipase dose of 40,000-50,000 $\mathrm{PhU}$ per main meal, and half that dose with snacks. That enzyme dose significantly improved the fat and protein digestion, symptoms, and nutritional status of patients with PEI in clinical trials [18]. To best evaluate the efficacy of PERT, it is imperative to assess both symptomatic improvement and normalization of nutritional parameters, since symptom resolution alone does not exclude residual PEI and ongoing malnutritionassociated consequences $[1-3,19]$.

The results of this in vitro study comparing eight formulations of PERT (five different brands) available in Russia and CIS (pancreatin in capsules in Russia/CIS with a label 


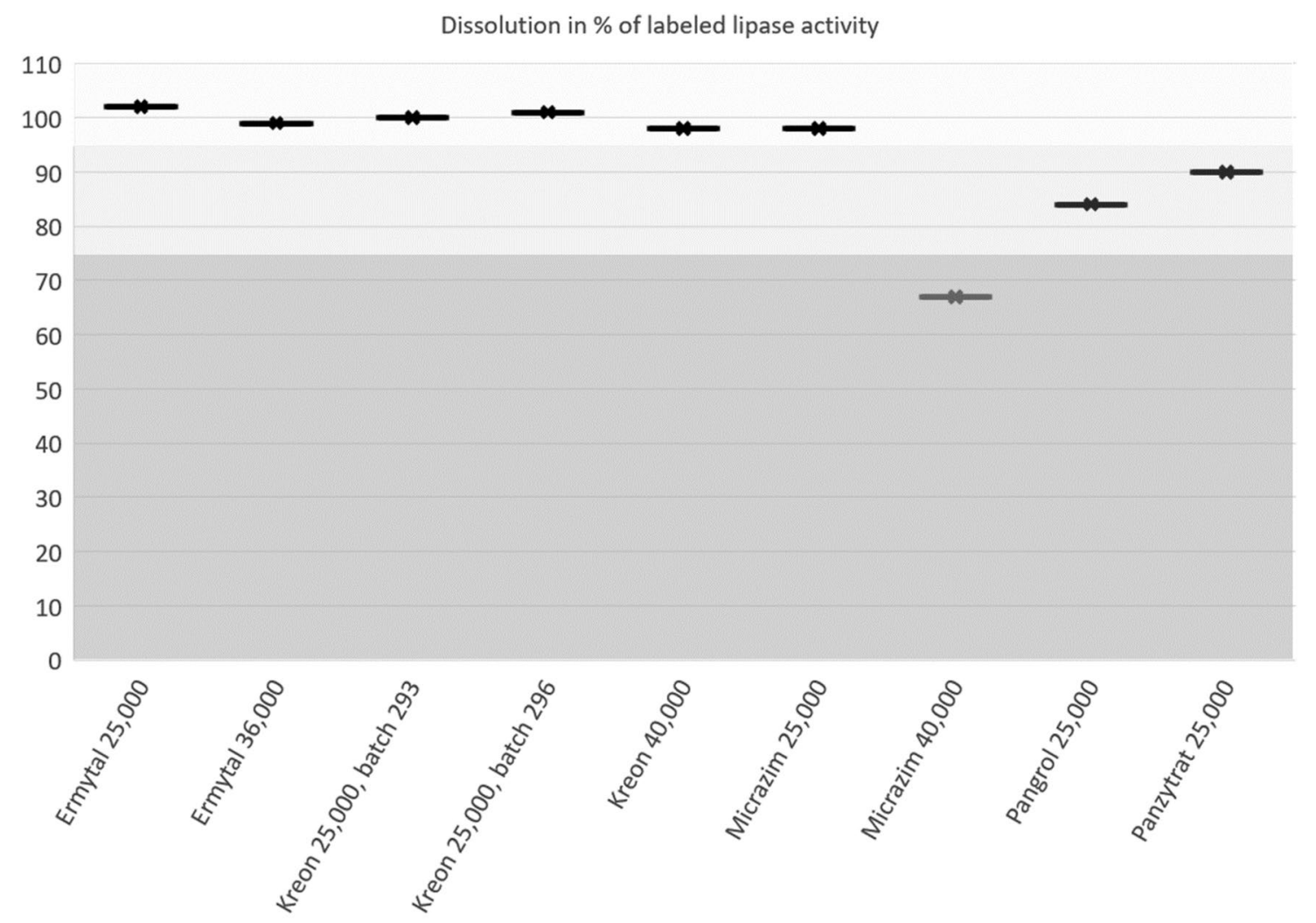

Fig. 3 Dissolution of the different products after $20 \mathrm{~min}$ as percent of labeled lipase activity (LC)

Table 4 Dissolution after 20 and 30 minutes at $\mathrm{pH} 6$ after $2 \mathrm{~h}$ incubation in $0.1 \mathrm{HCl}$ expressed as percent of labeled lipase activity (label claim)

\begin{tabular}{|c|c|c|c|}
\hline Product & Batch & $\begin{array}{l}\text { Mean }[\% \mathrm{LC}] \\
\text { after } 20 \mathrm{~min}(\mathrm{CV})\end{array}$ & $\begin{array}{l}\text { Mean }[\% \mathrm{LC}] \\
\text { after } 30 \mathrm{~min}(\mathrm{CV})\end{array}$ \\
\hline Ermytal ${ }^{\circledR} 25,000$ & 330401 & $102(5.2)$ & $95(4.6)$ \\
\hline Ermytal ${ }^{\circledR} 36,000$ & 110421 & $99(3.1)$ & $94(2.8)$ \\
\hline Kreon $® 25,000$ & 0293 & $100(2.3)$ & $97(1.5)$ \\
\hline Kreon ${ }^{\circledR} 25,000$ & 0296 & $101(1.8)$ & $97(1.7)$ \\
\hline Kreon ${ }^{\circledR} 40,000$ & 0014 & $98(2.1)$ & $93(2.1)$ \\
\hline Micrazim ${ }^{\circledR} 25,000$ & 33041 & $98^{\mathrm{a}}$ & $99^{\mathrm{a}}$ \\
\hline Micrazim ${ }^{\circledR} 40,000$ & 10716 & $67(5.7)$ & $62(5.9)$ \\
\hline Pangrol ${ }^{\circledR} 25,000$ & 71200 & $84(9.9)$ & $94(11.6)$ \\
\hline Panzytrat ${ }^{\circledR} 25,000$ & 410101 & $90(3.7)$ & $86(2.5)$ \\
\hline
\end{tabular}

$C V$ coefficient of variation, $L C$ labelled content

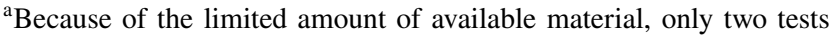
were performed, instead of six, so no $\mathrm{CV}$ is reported

claim of $\geq 25,000$ ) demonstrated little difference regarding lipase activities compared with the labeled content, with the exception of Micrazim ${ }^{\circledR}$ 25,000 and 40,000, which contained $96 \%$ and $79 \%$ of the labeled content of lipase, respectively. Regarding dissolution, most of the products exhibited a reproducible dissolution rate combined with an acceptable level of $>80 \%$ of labeled lipase activity. To conclude, this means that the enzymes are, in most cases, efficiently protected from gastric acid during the gastric phase and quickly released at $\mathrm{pH} 6$ (in the duodenum). As long as the (mini) microspheres or the minitablets are passing the pylorus due to their particle size the enzymes are released and will be active in the small intestine. There are two relevant exceptions in this study. First, Micrazim ® 40,000 released a maximum of $67 \%$ of labeled lipase activity. Given the low actual lipase activity of $79 \%$ of that claimed on the label, the dissolution rate in relation to actual lipase activity is approximately $80 \%$. This leads to the conclusion that the low dissolution rate as percent of label claim is mainly driven by the low lipase activity. Second, Pangrol@ 25,000 demonstrated a highly variable dissolution rate. The average release rate was still around or above $80 \%$, but several individual data points were below $80 \%$. The high variability (CV of $11.6 \%$ after 30 minutes) suggests that the patient will not receive a comparable lipase activity representing the labeled lipase activity with each dose, every time. Most formulations show a maximum dissolution rate after 20 minutes, but for Pangrol ${ }^{\circledR} 25,000$, this occurred after 30 minutes. Rapid release of enzymes in the duodenum is very important for PERT efficacy, as a release further distally impacts efficacy 
as it fails to mimic the natural postprandial exocrine pancreatic physiology [1-3].

This study confirms the results previously reported by Löhr et al. [13, 14]. Regarding PSD, significant differences were found between the different enzyme supplements. Meyer et al. [20] postulated that, in order to emulate physiology, particle size should not exceed $1.4 \pm 0.3 \mathrm{~mm}$, and that this size would ensure simultaneous emptying from the stomach interspersed in the chyme. Bruno et al. [21] demonstrated dyssynchronization in the gastric transit of a 2 $\mathrm{mm}$ pancreatin preparation and the meal. Kühnelt et al. [22] and Norregaard et al. [23] further confirmed that smaller particles had a different onset of action from larger particle diameters and that this translated into tangible differences in treatment efficacy; in particular, more rapid onset of action was associated with greater efficacy of PERT. Kuhnelt et al. [22], based on their study on gastric emptying of particles, advocated a pancreatin preparation with a granule size of $<1.2 \mathrm{~mm}$ and have previously demonstrated together with Mundlos et al. [24], that pellets with a particle size of $2.0 \mathrm{~mm}$ are retained $120 \mathrm{~min}$ longer in the stomach [22, 24]. Both Kühnelt et al. [22] and Layer et al. [25] also noted that products with a small particle size of $0.8-1.2 \mathrm{~mm}$ yielded higher lipolytic activity than particles measuring more than $1.8-2 \mathrm{~mm}$. Data are supportive of the recent investigations of Kong and Singh [26], which report that liquids and small particles $(<1-2 \mathrm{~mm})$ flow continuously from the stomach into the duodenum, whereas the indigestible particles larger than the pyloric opening are retropelled and retained in the stomach. Liquids and digestible and indigestible solids with a size of 1-2 $\mathrm{mm}$ are emptied during fed motility from the stomach to the duodenum, whereas contents $>2 \mathrm{~mm}$ are emptied during fasting motility [26].

The geometrical form of the investigated products (miniand microtablets, pellets, and minimicrospheres) is best described by a cylinder. The Ferret min diameter represents the diameter of this cylinder, whereas the Ferret max represents the length of the cylinder. As the Ferret max describes the maximum size of the particle in any dimension, it can be regarded as the main particle size parameter indicating the probability of a particle passing the pylorus together with the chyme.

As expected, the particle size for products that contain mini- or microtablets (Pangrol ${ }^{\circledR}$ and Ermytal ${ }^{\circledR}$ ) did not differ much. All the (mini- or micro-) tablets have a size of about $2.7 \mathrm{~mm}$, and Micrazim® pellets are slightly larger than $2.0 \mathrm{~mm}$. In contrast to these products, Kreon ${ }^{\circledR}$ contains minimicrospheres and the particle size is significantly smaller than the tablet and pellet formulations. The lower size determined for Kreon ${ }^{\circledR}$ products (around 1.6-1.7 mm) is aligned with the previous findings of Lohr et al. [13, 14] and the aforementioned statement in the HaPanEU guidelines that microspheres or mini-microspheres of $<2 \mathrm{~mm}$ are the preparations of choice for PEI (Statement 4-2.2) [1]. A particle size of less than $2000 \mu \mathrm{m}$ is regarded as favorable for digestive potency.

These days, pancreatin in capsules is the drug of choice for the treatment of PEI, and tablets are rarely used in clinical practice [1]. It is considered key that PERT mimics postprandial exocrine pancreatic physiology as much as possible $[2,3]$. However, a large number of drugs are available in capsules, which makes it difficult for the practitioner to choose. This study is not the first to compare the properties of pancreatin preparations [14]; however, unlike previous publications, we compared the pancreatin preparations most commonly available in Russia and the CIS region.

Caution is required when transferring/extrapolating the results of an in vitro study to clinical outcomes; however, in terms of demonstrating the efficacy of PERT, the most recently published HaPanEU guidelines acknowledged that the most recent and well-designed randomized controlled trials were conducted with enteric-coated minimicrospheres [1].

\section{Conclusion}

This in vitro study of PERT preparations available in Russia and CIS demonstrated both similarities and differences, particularly in relation to particle size, and identified one outlier relating to measured lipase activity versus labeled activity and a low dissolution rate. Other products were sufficiently high in lipase activity per label claim. The study successfully demonstrated the variability of key performance parameters, particularly in relation to particle size, which may affect the efficacy of PERT and, ultimately, clinical outcomes.

Acknowledgements The authors acknowledge the support of Abbott: Lisa Ohlmeyer for performing the lipase activity and dissolution testing and Sandra Hillmer for determining the PSDs.

\section{Declarations}

Funding The research was supported by Abbott Pharmaceuticals.

Conflicts of interest Igor V. Maev, Yury A. Kucheryavyy, and Natalya B. Gubergrits have no conflicts of interest that are directly relevant to the content of this article. Dr. J. Enrique Domínguez-Muñoz has received research grants from Abbott Pharmaceuticals and Mylan; payment for lectures from Abbott and Mylan; and paid consultancy from Mylan. Ingo Bonnacker, Ekaterina A. Shelest, and Gwendolyn P. Janssen-van Solingen are employed by Abbott Pharmaceuticals.

Ethics approval Not applicable.

Consent to participate Not applicable.

Consent for publication Not applicable. 
Availability of data and material Not applicable.

Code availability Not applicable.

Authors' contributions All authors have contributed equally to the study manuscript.

Open Access This article is licensed under a Creative Commons Attribution-NonCommercial 4.0 International License, which permits any non-commercial use, sharing, adaptation, distribution and reproduction in any medium or format, as long as you give appropriate credit to the original author(s) and the source, provide a link to the Creative Commons licence, and indicate if changes were made. The images or other third party material in this article are included in the article's Creative Commons licence, unless indicated otherwise in a credit line to the material. If material is not included in the article's Creative Commons licence and your intended use is not permitted by statutory regulation or exceeds the permitted use, you will need to obtain permission directly from the copyright holder. To view a copy of this licence, visit http://creativecommons.org/licenses/by-nc/4.0/.

\section{References}

1. Löhr JM, et al. United European Gastroenteroloy evidence-based guidelines for the diagnosis and therapy of chronic pancreatitis (HaPanEU). United Eur Gastroenterol J. 2017;5(2):153-99. https ://doi.org/10.1177/2050640616684695 (Epub 2017 Jan 16).

2. Dominguez-Munoz JE. Pancreatic enzyme therapy for pancreatic exocrine insufficiency. Curr Gastroenterol Rep. 2007;9:116-22.

3. Domínguez-Muñoz JE, Phillips M. Nutritional therapy in chronic pancreatitis. Nutr Manag Gastrointestinal Dis Gastroenterol Clin N Am. 2018;47(1):95-106.

4. Nikfarjam, M. et al. Australasian Pancreatic Club Pancreatic Enzyme Replacement Therapy Guidelines Working Group. Diagnosis and management of pancreatic exocrine insufficiency. Med J Aust 2017; 207(4):161-165. https://doi.org/10.5694/mja16.00851. (Published online: 21 Aug 2017)

5. Working party of the Australasian Pancreatic club, Smit RC, Smith SF, Wilson J, et al. Summary and recommendations from the Australasian guidelines for the management of pancreatic exocrine insufficiency. Pancreatology 2016;16:164-180 and guidelines: https://pancreas.org.au/wp-content/uploads/2016/01/ APC-GUIDELINES-2015.pdf. Accessed 15 Dec 2018

6. Hoffmeister A, et al. Englischsprachige version der S3-Leitlinie chronische pankreatitis. Z Gastroenterol. 2015;53:1447-95.

7. Takacs T, et al. Chronic Pancreatitis. Evidence based management guidelines of the Hungarian Pancreatic Study Group. Orv Hetil. 2015;2015:156-262.

8. Gheorghe $\mathrm{C}$, et al. Romanian guidelines on the diagnosis and management of exocrine pancreatic insufficiency. J Gastrointestin Liver Dis. 2015;24:117-23.
9. Frulloni L, et al. Italian consensus guidelines for chronic pancreatitis. Dig Liver Dis. 2010;42:S381-406.

10. Martinez J, et al. The Spanish Pancreatic Club recommendations for the diagnosis and treatment of chronic pancreatitis: part 1 diagnosis. Pancreatology. 2013;13:8-17.

11. De-Madaria E, et al. The Spanish Pancreatic Club recommendations for the diagnosis and treatment of chronic pancreatitis: part 2 (treatment). Pancreatology. 2013;13:18-28.

12. Somaraju UR, Solis-Moya A. Pancreatic enzyme replacement therapy for people with cystic fibrosis. Cochrane Database Syst Rev. 2014;10:CD008227.

13. Löhr JM. Exocrine pancreatic insufficiency. 1st and 2nd ed. Bremen, Uni Med, 2007 and 2010; ISBN-10:3837411818, ISBN13:978-3837411812. 2010

14. Löhr JM, et al. Properties of different pancreatin preparations used in pancreatic exocrine insufficiency. Eur J Gastroenterol Hepatol. 2009;21:1024-31.

15. Borowitz DS, Grant RJ, Durie PR, The Consensus Committee. Use of pancreatic enzyme supplements for patients with cystic fibrosis in the context of fibrosing colonopathy. J Pediatr. 1995;127:681-4.

16. European Pharmacopeia, Monograph 0350, Pancreas Powder. 2019.

17. USP43-NF38 - page 3384, Current DocID: GUID-B713FD296584-4961-8C46-4A56F436AB85_1_en-US, Pancrelipase Delayed-Release Capsules. 2019.

18. De la Iglesia-Garcia D, et al. Efficacy of pancreatic enzyme replacement therapy in chronic pancreatitis: systematic review and meta-analysis. Gut. 2017;66:1474-86.

19. Dominguez-Munoz JE, Iglesias-Garcia J, Vilarino- Insua M, et al. 13C-Mixed triglyceride breath test to assess oral enzyme substitution therapy in patients with chronic pancreatitis. Clin Gastroenterol Hepatol. 2007;5:484-8.

20. Meyer JH, et al. Human Postprandial gastric emptying of 1-3 millimeter spheres. Gastroenterology. 1988;94:114-9.

21. Bruno MJ, et al. Gastric transit and pharmacodynamics of a twomillimeter enteric coated pancreatin microsphere preparation in patients with chronic pancreatitis. Dig Dis Sci. 1998;43:203-13.

22. Kühnelt $P$, et al. Einfluss der Pelletgroesse eines Pankreasenzympraeparates auf die duodenale lipolytische Aktivitaet (in german). Z Gastroenterol. 1991;29:417-21.

23. Norregaard P, et al. Gastric emptying of pancreatin granules and dietary lipids in pancreatic insufficiency. Aliment Pharmaccol Ther. 1996;10:427-32.

24. Mundlos S, Kühnelt P, Adler G. Monitoring enzyme replacement therapy in exocrine pancreatic insufficiency using the cholesteryl octanoate breath test. Gut. 1990;31:1324-8.

25. Layer P, Grossger G, Dicke D, Ohe M, Goebell H. Enzyme pellet size and luminal nutrient digestion in pancreatic insufficiency. Digestion. 1992;52:100-1.

26. Kong F, Singh RP. Disintegration of solid foods in human stomach. J Food Sci. 2008;73(5):67-80. 